\title{
Reactivity of Small Oxoacids of Sulfur
}

\author{
Sergei V. Makarov ${ }^{1, *}$, Attila K. Horváth ${ }^{2}$ and Anna S. Makarova ${ }^{3}$ \\ 1 State University of Chemistry and Technology, Sheremetevskiy str. 7, 153000 Ivanovo, Russia \\ 2 Department of Inorganic Chemistry, Institute of Chemistry, Faculty of Sciences, University of Pécs, \\ Ifjúság u. 6, H-7624, Hungary \\ 3 G. A. Krestov Institute of Solution Chemistry of the Russian Academy of Sciences, Academicheskaya str., 1, \\ 153045 Ivanovo, Russia \\ * Correspondence: makarov@isuct.ru; Tel./Fax: +7(4932)327397
}

Received: 1 July 2019; Accepted: 24 July 2019; Published: 30 July 2019

check for updates

\begin{abstract}
Oxidation of sulfide to sulfate is known to consist of several steps. Key intermediates in this process are the so-called small oxoacids of sulfur (SOS)—sulfenic $\mathrm{HSOH}$ (hydrogen thioperoxide, oxadisulfane, or sulfur hydride hydroxide) and sulfoxylic $\mathrm{S}(\mathrm{OH})_{2}$ acids. Sulfur monoxide can be considered as a dehydrated form of sulfoxylic acid. Although all of these species play an important role in atmospheric chemistry and in organic synthesis, and are also invoked in biochemical processes, they are quite unstable compounds so much so that their physical and chemical properties are still subject to intense studies. It is well-established that sulfoxylic acid has very strong reducing properties, while sulfenic acid is capable of both oxidizing and reducing various substrates. Here, in this review, the mechanisms of sulfide oxidation as well as data on the structure and reactivity of small sulfur-containing oxoacids, sulfur monoxide, and its precursors are discussed.
\end{abstract}

Keywords: hydrogen sulfide; sulfoxylic acid; hydrogen thioperoxide; sulfur monoxide

\section{Introduction}

Reactive oxygen species, ROS (the most important ROS species are superoxide, hydrogen peroxide, hydroxyl radical, singlet oxygen, hypochlorous acid), occupy a central place in redox biology. They have almost equal importance to reactive nitrogen species, RNS, with nitric oxide (NO) and peroxynitrite $\mathrm{ONOO}^{-}$being the most well-known among these substances. Likewise, in cases of oxygen and nitrogen, they have reactive biologically relevant species. Consequently, sulfur may also form reactive species (RSS) when, for example, a -SH group is oxidized. The concept of RSS was advocated in 2001 [1]. Since then it has become apparent that reactive sulfur species play their own role in cellular function and homeostasis [1-6]. In our opinion, the most successful definition of RSS has been proposed by Gruhlke and Slusarenko "RSS are redox-active sulfur-containing molecules that are able, under physiological conditions, to either oxidize or reduce biomolecules" [3]. Reactive sulfur species include nonradical species: Thiols RSH, disulfides RSSR, and polysulfides $\mathrm{RS}_{\mathrm{n}} \mathrm{R}$, sulfenic acids $\mathrm{RSOH}$, thiosulfinates (disulfide-S-monoxides) RS(O)SR, thiosulfonates (disulfide-S-dioxides) $\mathrm{RS}(\mathrm{O}){ }_{2} \mathrm{SR}$, as well as thiyl radicals RS• [3]. It should be noted that the most well-known groups of RSS are cysteine (Cys) and its derivatives, especially cysteinesulfenic acid (Cys-SOH) $[7,8]$ and cysteine hydropersulfide CysSSH [9], with hydrogen sulfide being one of the most important signal molecules [10], along with disulfides $\mathrm{HSSH}$ and polysulfides $\mathrm{HS}_{\mathrm{n}} \mathrm{H}[4,5]$. The parent compounds in these groups are cysteine and hydrogen sulfide, both of which are reducing agents and contain -SH group. But, if for cysteine, it is recognized that oxidative pathways from cysteine leading eventually to cysteinesulfonic acid $\left(\mathrm{Cys}-\mathrm{SO}_{3} \mathrm{H}\right)$ via successive formation of cysteinesulfenic acid and cysteinesulfinic acid $\left(\mathrm{Cys}-\mathrm{SO}_{2} \mathrm{H}\right)$ are physiologically important, until 2018 the physiological importance of sulfur species was considered for only the short-lived hydrogen thioperoxide $(\mathrm{HSOH})$ and more stable polysulfides, but not the 
analogy of cysteinesulfinic acid—sulfoxylic (sulfinic) acid $\mathrm{S}(\mathrm{OH})_{2}$. The hydrogen sulfide-disulfide (polysulfides) pathway is considered as the main, if not the exclusive, route of physiologically important transformation of $\mathrm{H}_{2} \mathrm{~S}[4,5]$. It should be noted, however, that sulfoxylic acid is considered as an intermediate of the oxidation of hydrogen sulfide in vitro [11]. In this review we shall discuss the main properties and possible physiological role of the products of oxygenation of hydrogen sulfide-hydrogen thioperoxide and sulfoxylic acid, as well as the product of hypothetical dehydration of $\mathrm{S}(\mathrm{OH})_{2}$-sulfur monoxide $\mathrm{SO}$.

Small oxoacids of sulfur (SOS), $\mathrm{HSOH}$, and $\mathrm{S}(\mathrm{OH})_{2}$ stand in the middle of so-called sulfur cycle from sulfide to sulfate, between elemental sulfur and sulfite. Though they occupy a central part of this cycle and include compounds containing sulfur in two oxidation states $(0,+2)$, their properties have been scarcely studied. However, recent studies showed [12] that they play a significant role in many important processes, especially in the oxidation of hydrogen sulfide. Sulfoxylic acid (sulfoxylate) is the reactive intermediate of the processes, with participation of industrially important reductants-thiourea dioxide (TDO) and sodium hydroxymethanesulfinate [13]. Sulfur monoxide plays a valuable role in atmospheric chemistry and organic synthesis [14,15]. Recently, we have published a book [16], chapter of a book [17], and a review [18] where, in detail, properties of sulfoxylic acid, its derivatives, and precursors, especially thiourea dioxides, are discussed. From the appearance of these manuscripts, however, some important papers have been published which, in our opinion, deserve the attention of wider audience and will be discussed in detail. Reviews describing properties of hydrogen thioperoxide and sulfur monoxide are absent at all. These are the main reasons why we decided to present a review combining data of reactive sulfur-oxygen species mentioned above. It should, however, be noted that in this review we do not consider dithionites (compounds with sulfur in oxidation state +3 ), including sodium dithionite $\mathrm{Na}_{2} \mathrm{~S}_{2} \mathrm{O}_{4}$, since the chemistry of these compounds is much more thoroughly known and has been described recently in our review [19] and book [16]. The more recent papers on sodium dithionite focus on only developing and exploiting its well-known application as a strong reducing agent. We shall mention dithionites (dithionous acid) and the product of its monomerization-sulfur dioxide anion radical $\mathrm{SO}_{2}{ }^{\bullet-}$ just in connection with the other sulfur species.

Among sulfur compounds under review, sulfoxylates are the most well-known and important species. This could be explained by the practical importance of their precursors-sodium hydroxymethanesulfinate (rongalite) $\mathrm{HOCH}_{2} \mathrm{SO}_{2} \mathrm{Na}$ (note: its other name is sodium formaldehyde sulfoxylate) and thiourea dioxide $\left(\mathrm{NH}_{2}\right)_{2} \mathrm{CSO}_{2}$.

\section{SOS as the Intermediates of Hydrogen Sulfide Oxidation}

In principle, the most affordable routes to hydrogen thioperoxide and sulfoxylate could be the oxidation of hydrogen sulfide (sulfides) $[11,20]$ or sulfur [21,22] and reduction (chemical or electrochemical) of dithionite $\mathrm{S}_{2} \mathrm{O}_{4}{ }^{2-}$ (sulfur dioxide anion radical $\mathrm{SO}_{2}{ }^{\bullet-}$ ) [23-25]. The initial step in the one-electron $\mathrm{H}_{2} \mathrm{~S}$ oxidation to form $\mathrm{HSO}^{\bullet}$ (hydroxysulfinyl) radical and the final step in converting $\mathrm{SO}_{2}$ to sulfuric acid have been studied extensively [20]. In contrast, very little is known about oxygenated sulfur species in which sulfur is in the intermediate +1 to +4 oxidation states. The first preparation of hydroxysulfinyl radical in the gas phase has been performed by Frank and coworkers [20]. Reactions of $\mathrm{HSO}^{\bullet}$ with oxygen, ozone, $\mathrm{NO}$, and $\mathrm{NO}_{2}$ have been studied by Tyndall and Ravishankara [26]. Laboratory measurements and astronomical searches for the $\mathrm{HSO}^{\bullet}$ radical indicate that this molecule does not achieve significant abundances either in the gas phase or in the ice mantles of dust grains [27]. Hydroxysulfinyl radical was predicted to undergo exothermic reaction with $\left({ }^{3} \Sigma\right) \mathrm{O}_{2}$ to yield $\mathrm{SO}_{2}$ [20]. Radical $\mathrm{HSO}^{\bullet}$ is a reduced form of the hydroxysulfinyl cation $\mathrm{HSO}^{+}$. The latter was prepared by protonation of sulfur dioxide with $\mathrm{CH}_{5}{ }^{+}$. Collisional neutralization of $\mathrm{HSO}^{+}$by organic molecules yielded hydroxysulfinyl radical. The cation radical of sulfoxylic acid (authors [20] refer to $S(O H)_{2}$ as sulfinic acid) was generated by dissociative ionization of dimethyl sulfate. Collisional neutralization of $\mathrm{S}(\mathrm{OH})_{2}{ }^{+}$yielded stable molecules of sulfoxylic acid. The formation of hydroxysulfinyl radical and sulfoxylic acid in the gas phase has been proven by mass spectrometry. 
Betterton and Hoffmann supposed a heterolytic (polar) mechanism of reaction between hydrogen sulfide and peroxides [11]. The primary intermediate of this reaction is $\mathrm{HSOH}$ :

$$
\mathrm{H}_{2} \mathrm{~S}+\mathrm{H}_{2} \mathrm{O}_{2} \rightarrow \mathrm{HSOH}+\mathrm{H}_{2} \mathrm{O}
$$

The next step is accompanied by formation of sulfoxylic acid:

$$
\mathrm{HSOH}+\mathrm{H}_{2} \mathrm{O}_{2} \rightarrow \mathrm{S}(\mathrm{OH})_{2}+\mathrm{H}_{2} \mathrm{O}
$$

On the other hand, reaction of $\mathrm{S}(\mathrm{OH})_{2}$ with $\mathrm{HS}^{-}$could account for the formation of polysulfides:

$$
\mathrm{HSOH}+\mathrm{HS}^{-} \rightarrow \mathrm{HS}_{2}{ }^{-}+\mathrm{H}_{2} \mathrm{O}
$$

Earlier, Čermák has shown [24] that sulfoxylic acid can be received by electrochemical reduction of sulfur dioxide anion radical $\mathrm{SO}_{2}{ }^{\bullet}\left(\mathrm{HSO}_{2}{ }^{\bullet}\right)$, which is formed in aqueous solutions of sodium dithionite:

$$
\mathrm{HSO}_{2}^{-\bullet}+\mathrm{e} \rightarrow \mathrm{SO}_{2} \mathrm{H}^{-}
$$

The formation of sulfoxylate $\mathrm{SO}_{2}{ }^{2-}$ in the course of sulfide oxidation in solution has been observed by Vairavamurthy and Zhou [28]. They studied the oxidation of $0.1 \mathrm{M}$ sulfide solutions under conditions of high sulfide-to-oxygen ratios using X-ray absorption near edge structure (XANES) spectroscopy and Fourier transform infrared (FT-IR) spectroscopy. Vairavamurthy and Zhou have noted that lowering the $\mathrm{pH}$ of solution to 8.5 causes the $918 \mathrm{~cm}^{-1}$ absorption to disappear. According to Tossell [29], only the presence of protonated species $(\mathrm{OH}) \mathrm{SO}^{-}$in the original solution (with $\mathrm{pH}$ 11.5-12) would explain the presence of the $918 \mathrm{~cm}^{-1}$ peak and its disappearance upon acidification. Later, Crabtree and coworkers detected sulfoxylic acid using Fourier transform microwave spectroscopy and double resonance techniques, guided by new high-level $\operatorname{CCSD}(\mathrm{T})$ quantum chemical calculations of its molecular structure [30]. In accordance with earlier studies [29,31] their electronic structure calculations have shown that the lowest energy configurations of $\mathrm{H}_{2} \mathrm{SO}_{2}$ in vacuum are rotamers of sulfoxylic acid (denoted $\mathrm{S}(\mathrm{OH})_{2}$ ), where the protons are bound to each of the oxygen atoms. Other isomers of $\mathrm{H}_{2} \mathrm{SO}_{2}$ of potential significance are those termed sulfinic acid, where one proton is bound to the sulfur atom and the other to one of the oxygen atoms (denoted: ( $\mathrm{HS}) \mathrm{O}_{2} \mathrm{H}$ ). The relative stabilities of these isomers in solution are not constrained, nor are the isomers of bisulfoxylate: ( $\mathrm{HS} \mathrm{O}_{2}{ }^{-}$and (HO)SO${ }^{-}$[32].

Studies on hydrogen thioperoxide are very sparse. It was detected in an argon matrix during the course of photolysis of ozone and hydrogen sulfide [33], and was generated from an $\mathrm{H}_{2} \mathrm{~S} / \mathrm{N}_{2} \mathrm{O}$ mixture in a chemical ionization source [34]. But these synthetic routes are suited to prepare only very small quantities of $\mathrm{HSOH}$. Winnewisser and coworkers have suggested another route to prepare hydrogen thioperoxide: Gas-phase $\mathrm{HSOH}$ was synthesized by flash vacuum pyrolysis of di-tert-butyl sulfoxide [35] (Scheme 1):<smiles>C=CC(C)(C)S(=O)(=O)OCC</smiles>

Di-tert-butyl sulfoxide

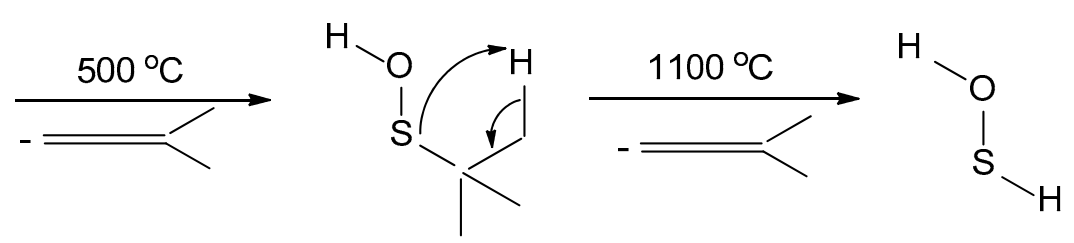

tert-Butylsulfenic acid

Scheme 1. Gas phase synthesis of hydrogen thioperoxide. Reproduced with permission from [35].

Investigations of the pyrolysis reaction by mass spectrometry, matrix isolation, and gas phase FT-IR spectroscopy revealed that up to $500{ }^{\circ} \mathrm{C}$ di-tert-butyl sulfoxide decomposes selectively into tert-butylsulfenic acid, $(t \mathrm{BuSOH})$, and 2-methylpropene. Transient tert-butylsulfenic acid has been 
characterized by a comprehensive matrix and gas phase vibrational IR study guided by the predicted vibrational spectrum calculated at the density functional theory (DFT) level (B3LYP/6-311+G(2d,p)). At higher temperatures, the intramolecular decomposition of tert-butylsulfenic acid, monitored by matrix IR spectroscopy, yields short-lived hydrogen thioperoxide along with 2-methylpropene, but also $\mathrm{H}_{2} \mathrm{O}$, and most probably sulfur atoms [36].

Recently Kumar and Farmer have found that small oxoacids of sulfur sulfenic ( $\mathrm{HSOH}$, hydrogen thioperoxide), sulfoxylic $\left(\mathrm{H}_{2} \mathrm{SO}_{2}\right)$, and thiosulfoxylic $\left(\mathrm{H}_{2} \mathrm{~S}_{2} \mathrm{O}_{2}\right)$ acids may be trapped in situ by derivatization with nucleophilic and electrophilic trapping agents [12]. The generated SOS are derivable from reactions with nucleophilic traps such as dimedone and 1-trimethylsiloxycyclohexene, as well as electrophilic traps such as iodoacetamide and mono- or dibromobimane. Kumar and Farmer have compared SOS formation from $\mathrm{H}_{2} \mathrm{~S}$ oxidation with a variety of biologically relevant oxidants (hydrogen peroxide, hypochlorous acid, metmyoglobin (Mb), microperoxidase (MP-11), hydroxocobalamin $(\mathrm{Cbl})$ ) as well as maleic peroxide. All reactions were done in the ratio of $1 \mathrm{mM} \mathrm{H}_{2} \mathrm{~S}$, $1.2 \mathrm{mM}$ oxidant at buffered condition around $\mathrm{pH}=7$. Peroxides and $\mathrm{HOCl}$ were expected to directly form the SOS by O-atom transfer (see reaction 1).

Authors have assumed that metalloproteins and $\mathrm{Cbl}$ initially oxidize hydrogen sulfide by outer sphere mechanism via one-electron mechanism, for example:

$$
2 \mathrm{Cbl}(\mathrm{III})+\mathrm{H}_{2} \mathrm{~S}+\mathrm{H}_{2} \mathrm{O} \rightarrow \mathrm{H}_{2} \mathrm{SO}+2 \mathrm{Cbl}(\mathrm{II})+2 \mathrm{H}^{+}
$$

$\mathrm{HOCl}$ was the most selective oxidant at producing $\mathrm{HSOH}$, with $\mathrm{H}_{2} \mathrm{O}_{2}$ yielding 3:2 mixtures of $\mathrm{HSOH}$ and $\mathrm{HOSOH}$. All of the metalloprotein oxidants generated measurable SOS, with MP-11 the more selective for formation of $\mathrm{HSOH}$ over $\mathrm{HOSOH}$. Several polysulfides $\mathrm{SOS}\left(\mathrm{H}_{2} \mathrm{~S}_{n} \mathrm{O}_{m}\right)$ were also observed in these reactions. The harder oxidants were, the more persulfanes were generated; for example, the ranking of observed efficiency of $\mathrm{HS}_{3} \mathrm{OH}$ formation was peroxide $>$ hypochlorite $>$ $\mathrm{MP}>\mathrm{MP}-11>\mathrm{Mb}>\mathrm{Cbl}$.

In opinion of Nagy and coworkers [37], the trapping methodology with alkylating agents applied by Kumar and Farmer [12] does not deny the possibility that trapped $\mathrm{HSOH}$ could have been produced from the hydrolysis of polysulfides to be reacted rapidly with another sulfide molecule:

$$
\mathrm{HSOH}+\mathrm{H}_{2} \mathrm{~S} \rightarrow \mathrm{HSSH}+\mathrm{H}_{2} \mathrm{O}
$$

to generate disulfide species in analogy with the reaction of cysteine sulfenic acid $\mathrm{CySOH}$ with cysteine [38]:

$$
\mathrm{CySOH}+\mathrm{CySH} \rightarrow \mathrm{CySSCy}+\mathrm{H}_{2} \mathrm{O} .
$$

Theoretical calculations suggest a chemical mechanism that takes advantage of the interaction between sulfur oxides, $\mathrm{SO}_{n}(n=1,2,3)$ and hydrogen sulfide $\left(n \mathrm{H}_{2} \mathrm{~S}\right)$, resulting in the efficient formation of a $S_{n+1}$ particle. Reaction (8) occurs via low-energy pathways under water or sulfuric acid catalysis [39].

$$
\mathrm{SO}_{\mathrm{n}}+n \mathrm{H}_{2} \mathrm{~S} \rightarrow \mathrm{S}_{\mathrm{n}+1}+n \mathrm{H}_{2} \mathrm{O}
$$

Polysulfanes oxides may arise from initially formed SOS reacting with $\mathrm{H}_{2} \mathrm{~S}$ :

$$
\mathrm{HOSOH}+\mathrm{H}_{2} \mathrm{~S} \rightarrow \mathrm{HSSOH}+\mathrm{H}_{2} \mathrm{O} .
$$

It should be noted that nowadays a generally recognized opinion exists in the literature, on the basis of mechanistic grounds, about the possibility that sulfide oxidations most likely proceed via sulfenic acid (hydrogen thioperoxide) intermediate species, just as in the case of cysteine (Cys) [37,40-42]. The fate of $\mathrm{HSOH}$ can either be reaction with another nucleophile (e.g., Cys or $\mathrm{HS}^{-}$) or with another oxidant molecule (depending on the relative reactivities and concentrations of the reactants) [43]. Interestingly, in the scheme of HSOH oxidation, which is a part of hydrogen sulfide oxidation, discussed 
in the review of Alvarez and coworkers [41], the intermediate stages of the oxidation of hydrogen thioperoxide at larger oxidant concentrations were not indicated (see: Scheme 2), i.e., formation of sulfoxylic or dithionous acids are not considered.

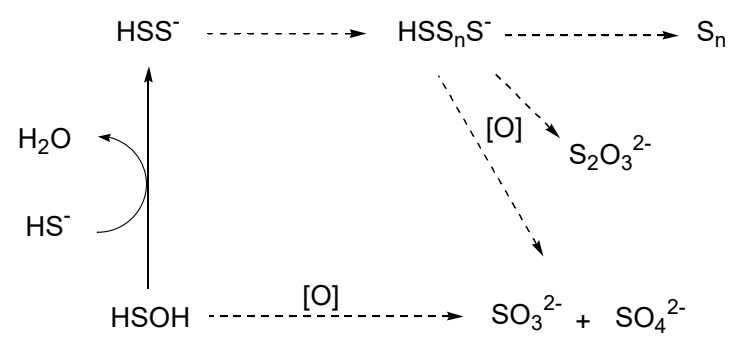

Scheme 2. Oxidation of hydrogen thioperoxide. Reproduced with permission from [41].

In the case of hydrogen peroxide, the final products depend on the initial ratio of hydrogen peroxide to $\mathrm{H}_{2} \mathrm{~S}$, and consist mainly of polysulfides, elemental sulfur, and, in the presence of oxidant excess, sulfate [40]. Unfortunately, there are only scarce data on the influence of the ratio of hydrogen sulfide and oxidant concentrations on the mechanism of the $\mathrm{H}_{2} \mathrm{~S}$ oxidation. One possible example is the reaction of $\mathrm{H}_{2} \mathrm{~S}$ with $\mathrm{Cbl}(\mathrm{III})$. As mentioned above, at $\left[\mathrm{H}_{2} \mathrm{~S}\right] \approx[\mathrm{Cbl}(\mathrm{III})]$ experimental conditions on the intermediate stages of their reaction, the formation of hydrogen thioperoxide and sulfoxylic acid was observed [12]. Toohee has shown [44] that hydrosulfide displaces $\mathrm{H}_{2} \mathrm{O}$ or cyanide from cobalamin or cobinamide (Cbi differs from the aquacobalamin by the absence of dimethylbenzimidazole axial ligand) to give $\mathrm{Co}$ (II) complex. Salnikov and coworkers have studied the reaction between $\mathrm{Cbl}(\mathrm{III})$ (hydroxocobalamin) and $\mathrm{H}_{2} \mathrm{~S}$ at large excess of hydrogen sulfide at $\mathrm{pH} 1-10$ range [45]. The reaction proceeds in three steps: formation of the complex between aquacobalamin and hydrogen sulfide, inner-sphere electron transfer with formation of $\mathrm{Cbl}(\mathrm{II})-\mathrm{S}^{\bullet-}$ complex, and addition of a second molecule of hydrogen sulfide to the reduced cobalamin (the last step is shown in Scheme 3).

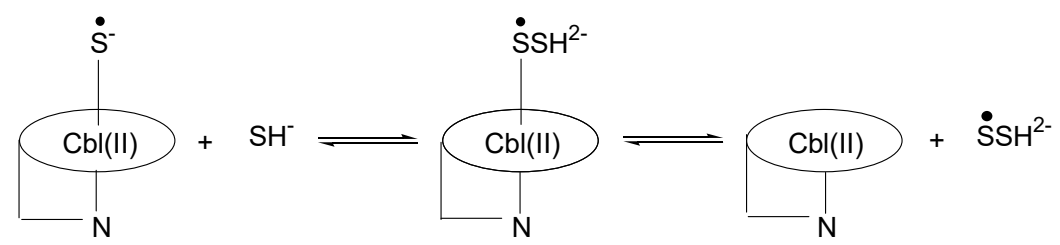

Scheme 3. Last step of the reaction between aquacobalamin and hydrogen sulfide. Reproduced with permission from [45].

A stable complex between $\mathrm{H}_{2} \mathrm{~S}$ and $\mathrm{Cbl}$ (III) could be generated, but only in strongly acidic solutions. When the aqueous $\mathrm{H}_{2} \mathrm{~S}-\mathrm{Cbl}$ (III) solution was exposed to bubbling air at $\mathrm{pH} 7$ to 8 , the product of $\mathrm{H}_{2} \mathrm{~S}-\mathrm{Cbl}$ (III) reaction was converted to sulfitocobalamin at a relatively high yield [45]. These data also show that in the course of hydrogen sulfide-quacobalamin reaction, a radical $\mathrm{HS}^{\bullet}\left(\mathrm{S}^{\bullet-}\right)$ is formed since hydrosulfide ion $\mathrm{HS}^{-}$is not very reactive but hydrosulfide radical $\mathrm{HS}^{\bullet}\left(\mathrm{S}^{\bullet-}\right)$ is highly reactive towards dioxygen, resulting eventually in the formation of sulfite as a product $[46,47]$ :

$$
\begin{gathered}
\mathrm{S}^{\bullet-}+\mathrm{O}_{2} \rightarrow \mathrm{SO}_{2}^{\bullet-} \\
\mathrm{SO}_{2}^{\bullet-}+\mathrm{O}_{2} \rightarrow \mathrm{SO}_{2}+\mathrm{O}_{2}^{\bullet-}
\end{gathered}
$$

In the same year Salnikov and coworkers showed that the main product of the reaction between cobinamide and hydrogen sulfide at $\left[\mathrm{H}_{2} \mathrm{~S}\right]>>[\mathrm{Cbi}]$ is a complex of cobinamide(II) with the anion radical $\mathrm{SSH}^{\bullet 2-}$ [48]. Thus, data mentioned above show that the relative concentrations of hydrogen sulfide and oxidant strongly influence the composition of products of their reactions.

Besides relative concentrations of the reagents, the compositions of products of hydrogen sulfide oxidation will, of course, depend on the relative reactivity of $\mathrm{H}_{2} \mathrm{~S}$ and oxidant toward HSOH. However, 
there are no data on the kinetics of these reactions. Carballal and coworkers [49] mentioned the rate coefficient for reaction between $\mathrm{HSOH}$ and $\mathrm{HS}^{-}$, but indicate in the footnote that this value has been reported for cysteine. Rabai and coworkers [42] reported the rate coefficients for reactions of $\mathrm{HSOH}$ with $\mathrm{H}_{2} \mathrm{O}_{2}$ and $\mathrm{HS}^{-}\left(0.04\right.$ and $100 \mathrm{M}^{-1} \mathrm{~s}^{-1}$, respectively), but these data have been determined from simulations, not from direct experiments. The most promising way to get kinetic data is to accumulate $\mathrm{HSOH}$ from some sources in aqueous solution. In principle, as a source, a compound with $\mathrm{SO}(\mathrm{SOH})$ fragment may easily be conceivable, for example, thiourea monoxides (by analogy with thiourea dioxide as a source of sulfoxylate, see below $[16,18])$.

\section{Thiourea Oxides as the Sources of SOS}

Thiourea oxides are formed in the course of oxidation of thiourea by hydrogen peroxide or peracetic acid [16]. Relative stability of thiourea mon-, di-, and trioxides strongly depends on the structure of thiourea $\left(R^{1} R^{2}\right) N\left(R^{3} R^{4}\right) N C S$. If at least one substituent $R$ is a hydrogen atom, thioureas form relatively stable dioxides and trioxides. Tetraalkylthioureas, for example, tetramethylthiourea form in aqueous solutions relatively stable monoxides in the course of oxidation by bromine, bromate [50], chlorite [51], and hydrogen peroxide [52]; while formation of tetramethylthiourea dioxide and trioxide has not been observed at all. Indeed, higher oxides were earlier shown to be unavailable by means of oxidation of tetramethylthiourea by peroxides and alternative pathways of synthesis should be employed [53,54]. Tetramethylthiourea trioxide has been received in reaction between 1-chloro-tetramethylformamidinium chloride with silver sulfite [53]. Formation of tetramethylurea and sulfate as the final products of oxidation of tetramethylthiourea [52], together with the absence of dioxide and trioxide, show that cleavage of C-S bond proceeds at the monoxide stage. Therefore, it is reasonable to assume that the primary sulfur-containing product of tetramethylthiourea monoxide decomposition is hydrogen thioperoxide:

$$
\left(\mathrm{CH}_{3}\right)_{4} \mathrm{~N}_{2} \mathrm{CSO}+\mathrm{H}_{2} \mathrm{O} \rightarrow\left(\mathrm{CH}_{3}\right)_{4} \mathrm{~N}_{2} \mathrm{CO}+\mathrm{HSOH}
$$

Thus, thiourea monoxide can be considered as a source of hydrogen thioperoxide in aqueous solution.

An interesting mechanistic feature may be highlighted in the case of a reaction between hydrogen sulfide and chlorine dioxide [55]. This reaction can be divided into two separate kinetic stages. The first stage is very fast, the second one proceeds much more slowly. Authors have compared their results with the data on kinetics of reactions between chlorine dioxide and thiosulfate or sulfite [56,57]. It is shown that these reactions start with electron transfer from the substrate to chlorine dioxide and with oxygen transfer from chlorine dioxide to the substrate, simultaneously. Authors [55] have shown, however, that analogous initiation step

$$
\mathrm{HS}^{-}+{ }^{\bullet} \mathrm{ClO}_{2} \rightleftharpoons \cdot{ }^{\bullet} \mathrm{HS}+\mathrm{ClO}_{2}^{-}
$$

does not proceed. Instead of this, the fast formation of the weak adduct ${ }^{\bullet} \mathrm{HSClO}_{2}{ }^{-}$is observed:

$$
\mathrm{HS}^{-}+{ }^{\bullet} \mathrm{ClO}_{2} \rightleftharpoons{ }^{\bullet} \mathrm{HSClO}_{2}^{-}
$$

The next step is accompanied by formation of sulfide radical and chlorite:

$$
\cdot \mathrm{HSClO}_{2}{ }^{-}+\mathrm{OH}^{-} \rightarrow{ }^{\bullet} \mathrm{S}^{-}+\mathrm{ClO}_{2}{ }^{-}+\mathrm{H}_{2} \mathrm{O}
$$

A parallel decomposition of ${ }^{\bullet} \mathrm{HSClO}_{2}{ }^{-}$produces chlorine radical and sulfoxylate:

$$
{ }^{\bullet} \mathrm{HSClO}_{2}{ }^{-} \rightarrow \mathrm{SO}_{2} \mathrm{H}^{-}+{ }^{\bullet} \mathrm{Cl}
$$


Importantly, contrary to reactions of hydrogen sulfide with peroxides, authors do not assume formation of $\mathrm{HSOH}$ in the intermediate stages of the process.

In contrast to hydrogen thioperoxide there are some data on reactivity of sulfoxylic acid (sulfoxylate) received from direct experiments. The reason is the existence of convenient sources of sulfoxylate in aqueous solution - thiourea dioxide [58,59]. In alkaline solutions $(\mathrm{pH}>10)$ TDO decomposes with formation of sulfoxylate:

$$
\left(\mathrm{NH}_{2}\right)_{2} \mathrm{CSO}_{2}+\mathrm{OH}^{-} \rightarrow\left(\mathrm{NH}_{2}\right)_{2} \mathrm{CO}+\mathrm{SO}_{2} \mathrm{H}^{-}
$$

The only nitrogen-containing compound of TDO in strongly alkaline aqueous solutions is the redox inert urea, therefore it is possible to study reactivity of sulfoxylate without isolation of solid compounds. Importantly, sulfoxylate is relatively stable in alkaline solutions under anaerobic conditions and it is possible to accumulate it in solutions. Table 1 shows that at $\mathrm{pH} \approx 9$ sulfoxylate is even more stable than TDO [60].

Table 1. Rate constants for decomposition of thiourea dioxide (TDO), sulfoxylic acid, and sulfoxylate anions as a function of $\mathrm{pH}$.

\begin{tabular}{ccc}
\hline \multirow{2}{*}{$\mathbf{p H}$} & \multicolumn{2}{c}{$\mathbf{k} \cdot \mathbf{1 0}^{\mathbf{4}}, \mathbf{s}^{\mathbf{- 1}}$} \\
\cline { 2 - 3 } & Sulfoxylic Acid and Sulfoxylate Anions & TDO \\
\hline 9.04 & $0.42 \pm 0.07$ & $2.49 \pm 0.02$ \\
8.11 & $0.47 \pm 0.05$ & $0.45 \pm 0.04$ \\
7.94 & $0.64 \pm 0.05$ & $0.27 \pm 0.07$ \\
\hline
\end{tabular}

The other source of sulfoxylate in aqueous solutions is sodium hydroxymethanesulfinate (HMS). Contrary to TDO, HMS is unstable in acidic solutions:

$$
\mathrm{HOCH}_{2} \mathrm{SO}_{2}^{-} \rightleftharpoons \mathrm{SO}_{2} \mathrm{H}^{-}+\mathrm{CH}_{2} \mathrm{O}
$$

Sulfoxylic acid is also unstable in acidic solutions, therefore HMS is a less convenient source for accumulation of sulfoxylate than TDO. Anyway, accumulation of sulfoxylate in alkaline solutions of TDO and subsequent formation of hydroxymethanesulfinate in reactions of $\mathrm{SO}_{2} \mathrm{H}^{-}$with formaldehyde (reverse reaction 18) gave a possibility to determine the $\mathrm{pK}_{1}$ of sulfoxylic acid ( $\mathrm{pK} \mathrm{K}_{1} \approx 8.0$ ) [60].

Using of TDO as a source of sulfoxylate provided an opportunity to receive the first data of its reactivity from direct kinetic experiments. It was shown that sulfoxylate produces sulfur dioxide anion radical in reactions with dioxygen, superoxide, and hydrogen peroxide:

$$
\begin{gathered}
\mathrm{SO}_{2}{ }^{2-}+\mathrm{O}_{2} \rightarrow \mathrm{SO}_{2}{ }^{\bullet-}+\mathrm{O}_{2}{ }^{--} \\
\mathrm{SO}_{2}{ }^{2-}+\mathrm{O}_{2}{ }^{\bullet-} \rightarrow \mathrm{SO}_{2}{ }^{\bullet-}+\mathrm{O}_{2}{ }^{2-} \\
\mathrm{SO}_{2}{ }^{2-}+\mathrm{O}_{2}{ }^{2-}+2 \mathrm{H}_{2} \mathrm{O} \rightarrow \mathrm{SO}_{2}{ }^{\bullet-}+3 \mathrm{OH}^{-}+\mathrm{OH}^{\bullet}
\end{gathered}
$$

All of these reactions are very fast and proceed faster than corresponding reactions of sulfur dioxide anion radical [61]. Indeed, sulfoxylate and its source-thiourea dioxide, is a more powerful reducing agent than dithionite (dimer of sulfur dioxide anion radical). Thus, in contrast to dithionite, in alkaline solutions under anaerobic conditions sulfoxylate reduces methyl viologen cation $\left(\mathrm{MV}^{+}\right)$to fully reduced form [59]:

$$
\mathrm{SO}_{2}^{2-}+\mathrm{MV}^{+} \rightarrow \mathrm{SO}_{2}^{\bullet-}+\mathrm{MV}^{0}
$$

This reaction was the first example of chemical reduction of $\mathrm{MV}^{+}$to $\mathrm{MV}^{0}$ in aqueous solutions. The strong reducing properties of sulfoxylate are manifested in its ability to react with nitrite in strongly 
alkaline media [59]. This reaction was accompanied by the formation of dithionite, i.e., a one-electron oxidation of $\mathrm{SO}_{2}{ }^{2-}$ to $\mathrm{SO}_{2}{ }^{\bullet-}$, followed by dimerization of the sulfur dioxide anion radical.

$$
\begin{aligned}
& \mathrm{SO}_{2}{ }^{2-}+\mathrm{NO}_{2}{ }^{-} \rightarrow \mathrm{SO}_{2}{ }^{\bullet-}+\mathrm{NO}_{2}{ }^{2-} \\
& 2 \mathrm{SO}_{2}{ }^{\bullet-} \rightleftharpoons \mathrm{S}_{2} \mathrm{O}_{4}{ }^{2-}
\end{aligned}
$$

The possibility to reduce nitrite in strongly alkaline solutions in the absence of a catalyst is an important advantage of sulfoxylate (or its precursor-TDO). Most of the known reductions of nitrite were investigated in acidic and neutral media (see, for instance, [62]). In basic solutions the reaction of nitrite, for instance, with sodium borohydride, did not take place unless $\mathrm{Cu}(\mathrm{OH})_{2}$ was present [63]. It was also shown that sulfoxylate is capable of reducing nitrous and nitric oxides as well [59].

In alkaline solutions sulfoxylate does not react with sulfite [58]. It is known, however, that in slightly acidic solutions the addition of sulfite to the solution of sodium hydroxymethanesulfinate leads to the fast formation of dithionite [64] due to reactions (18) and (25):

$$
\mathrm{SO}_{2} \mathrm{H}^{-}+\mathrm{HSO}_{3}{ }^{-} \rightleftharpoons \mathrm{S}_{2} \mathrm{O}_{4}{ }^{2-}+\mathrm{H}_{2} \mathrm{O}
$$

Reducing properties of sulfoxylate (TDO) also allows the possibility to obtain unusual highly reduced metal complexes. Thus, contrary to dithionite, sulfoxylate gives a possibility to reduce formally $\mathrm{Fe}(\mathrm{I})(\mathrm{TSPc})^{5-}$ to $\mathrm{Fe}(\mathrm{I})(\mathrm{TSPc} \bullet)^{6-}$, where TSPc is tetrasulfophthalocyanine [65]. EPR spectroscopy was employed to demonstrate formation of reduced states of metallophthalocyanines in the course of their reactions with sulfoxylate [66]. At the same time, the catalytic effect of cobalt macroheterocyclic complexes in reduction of nitrite by TDO has been determined $[67,68]$. Higher reaction rate with sulfoxylate than with dithionite was observed in the studies of reduction of $\mu$-nitrido- and $\mu$-oxo-bridged iron phthalocyanines [69].

The kinetics of individual stages of reductive interaction of hydroxocobalamin with sulfoxylate in aqueous solutions, $\mathrm{Co}(\mathrm{III}) \rightarrow \mathrm{Co}(\mathrm{II})$ and $\mathrm{Co}(\mathrm{II}) \rightarrow \mathrm{Co}(\mathrm{I})$ ), have been investigated spectrophotometrically. The rate-limiting step in both reactions is the formation of intermediate complexes of sulfoxylate with $\mathrm{Cbl}(\mathrm{III})$ and $\mathrm{Cbl}(\mathrm{II})$, respectively [70].

As mentioned above, thioureas form stable dioxides only if in nitrogen containing fragments there is at least one hydrogen atom, i.e., thiourea dioxide should be stabilized by hydrogen bonds [71]. The existence of strong hydrogen bonds explain the relatively low solubility of TDO in water (about $2.5 \mathrm{~g}$ in $100 \mathrm{~mL}$ of water); besides, the presence of networks of hydrogen bonds in the solid TDO leads to the fact that it is not only poorly soluble in water but its dissolution is also a slow process [72,73]. It was shown recently that even in aqueous solutions TDO exists as a mixture of cyclic clusters of $\left(\mathrm{NH}_{2}\right)_{2} \mathrm{CSO}_{2}$ and single molecules of its isomer aminoiminomethanesulfinic acid (AIMSA) $\mathrm{NH}_{2} \mathrm{NHCSO}_{2} \mathrm{H}$ [74]. The slow decomposition of clusters and tautomerization to AIMSA explain the dependence of redox reactivity of thiourea dioxide on the age of its solution (time after dissolution) [75-78].

Modification of TDO structure, for example, insertion of aminoacid residue, leads to the formation of compounds with weaker hydrogen bonds and much higher solubility in water. Indeed, reaction of TDO with glycine in a slightly acidic media in the presence of sodium acetate gives a possibility to synthesize salt $\mathrm{O}_{2} \mathrm{SCNH}_{2} \mathrm{NHCH}_{2} \mathrm{COONa}$ [72], which can be used for receiving of much more concentrated solutions of sulfoxylate than can be received from TDO.

\section{Sulfur Monoxide}

Sulfur monoxide (SO) would be the hypothetical dehydrated form of $\mathrm{S}(\mathrm{OH})_{2}$, but it is not known to undergo hydrolysis to form sulfoxylic acid [79]. Sulfur monoxide and its dimer $\mathrm{S}_{2} \mathrm{O}_{2}$ are of great interest to astrophysics since they are abundant in the Venusian atmosphere [14]. SO is isovalence-electronic to $\mathrm{O}_{2}$ with a triplet ground state and features a S-O bond length of $1.481 \AA$ indicating double-bond character [80]. Sulfur monoxide is formed from $\mathrm{SO}_{2}$ under microwave discharge and by oxidation 
of elemental sulfur [80,81]. Both $\mathrm{SO}$ and $\mathrm{S}_{2} \mathrm{O}_{2}$ are unstable-disproportionation of SO leads to the formation of $\mathrm{S}$ and $\mathrm{SO}_{2}$ [80]. Two ${ }^{3} \mathrm{SO}$ produce two $\mathrm{S}_{2} \mathrm{O}_{2}$ isomers OSSO or SOSO, which both have a cis and a trans conformers. Cis- and trans-OSSO are both energetically favorable. Cis- and trans-SOSO are close in energy to free ${ }^{3} \mathrm{SO}+{ }^{3} \mathrm{SO}$ [14]. The formation and photochemical loss of OSSO have been discussed in detail by Kjaergaard and coworkers [14].

For synthetic purposes in organic chemistry, sulfur monoxide can be received in situ, for example, from thiirane oxide [82] or a trisulfide-2-oxide [83]. SO can be trapped by dienes or metal complexes [84-87]. Thus, heating trisulfide oxide (1) in the presence of dienes (2) results in transfer of sulfur monoxide to form cyclic unsaturated sulfoxides (3) in good to excellent yields, along with recovery of disulfide (4) (Scheme 4) [83]. Lemal and Chao have presented evidence that the triplet SO is formed exclusively as a thermal decomposition product of thiirane oxide. They have also discussed the mechanism of addition of triplet $\mathrm{SO}$ to dienes [88].

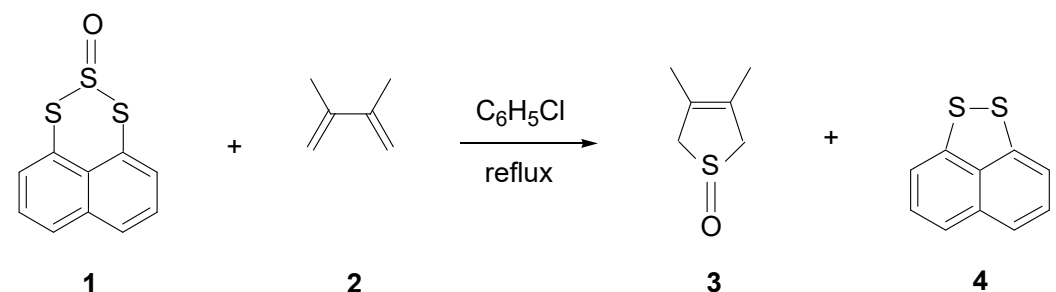

Scheme 4. Transfer of sulfur monoxide from trisulfide oxide to form cyclic unsaturated sulfoxide. Reproduced with permission from [83].

Stephan and coworkers have shown that a frustrated Lewis pair can be used for activation of $\mathrm{N}$-sulfinylamine which is a convenient source of SO [15]. Later Cummins and coworkers reported on synthesis and reactivity of a molecular precursor for $\mathrm{SO}$ generation, namely 7-sulfinylamino-7-azadibenzonorbornadiene (5) (Figure 1) [89]. This compound releases sulfur monoxide at mild temperatures $\left(<100^{\circ} \mathrm{C}\right)$ and allows for SO transfer, in solution, to organic molecules as well as transition metal complexes. Cummins and coworkers have shown that the formation of singlet $\mathrm{SO}$ is thermodynamically strongly favorable in the case of (5). ${ }^{3} \Sigma^{-} \mathrm{SO}$ was detected by microwave spectroscopy, possibly originating from ${ }^{1} \Delta \mathrm{SO}$ [89]. The singlet state is shown to be more reactive than the ground state, in analogy with molecular oxygen [90].

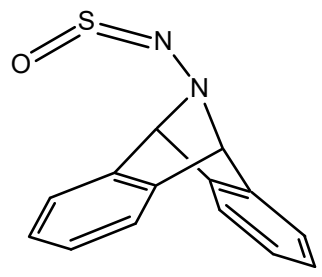

5

Figure 1. 7-sulfinylamino-7-azadibenzonorbornadiene.

\section{SOS in Reduction of Sulfite}

A very interesting biochemical aspect related to sulfur monoxide and/or sulfoxylate is their participation in reduction of sulfite. At the intracellular level, sulfite is a pivotal intermediate during microbial sulfate reduction (MSR). In contrast to chemical hydrogen sulfide oxidation, which proceeds relatively smoothly, the opposite reaction occurs in the sulfur cycle-reduction of sulfite remains inaccessible to synthetic catalysts [91].

Enzymatic reduction of sulfite $\left(\mathrm{SO}_{3}{ }^{2-}\right)$ requires the delivery of six electrons and seven protons (Equation (26)).

$$
\mathrm{SO}_{3}{ }^{2-}+6 \mathrm{e}^{-}+7 \mathrm{H}^{+} \rightarrow \mathrm{HS}^{-}+3 \mathrm{H}_{2} \mathrm{O}
$$


This reaction is driven by sulfite reductases ( $\mathrm{SiR}$ ) and goes to completion. The enzymes performing this reaction may be classified as dissimilatory ( $\mathrm{dSir}$ ) and assimilatory (aSir) ones. Both types contain a cofactor composed of a heme macrocycle (siroheme) and a cubane [4Fe- $4 \mathrm{~S}]$ cluster bridged by a cysteine residue. In recent biochemical models [92-96] reduction of sulfite at the siroheme-[4Fe-4S] catalytic site in dissimilatory sulfite reductase occurs in a stepwise fashion, first producing a bound $\mathrm{S}^{2+}$ intermediate, then a bound $S^{0}$ intermediate, before eventually leading to the formation of sulfide. aSir usually converts sulfite directly to hydrogen sulfide without generating intermediates; while dSir produces or reacts with the other sulfur compounds-thiosulfate $\mathrm{S}_{2} \mathrm{O}_{3}{ }^{2-}$ or trithionate $\mathrm{S}_{3} \mathrm{O}_{6}{ }^{2-}$ [92]. Reactions of enzymatically bound intermediates $\left(\mathrm{S}^{2+}, \mathrm{S}^{0}\right)$ via nucleophilic attack by residual nonenzymatically bound sulfite species have been hypothesized as pathways for the generation of thiosulfate and trithionate that have been observed in some MSR culture experiments [32,92].

However, whether trithionate and thiosulfate are really necessary intermediates still remains an open question [93]. Santos and coworkers assumed [94] that previous reports of thiosulfate and trithionate production were the result of nonphysiological in vitro conditions, for instance, unrealistically high (bi)sulfite concentrations.

Even if we assume that thiosulfate and trithionate are forming, the mechanism of their formation is unclear. As we discussed earlier, the primary product of the reaction between sulfoxylate and bisulfite is dithionite $\mathrm{S}_{2} \mathrm{O}_{4}{ }^{2-}$ (see reaction 25), but not thiosulfate or trithionate. The latter products can be formed as a result of decomposition of dithionite.

The other open question-what is $\mathrm{S}^{2+}$ species forming during sulfite reduction, sulfur monoxide or sulfoxylic acid (sulfoxylate)? As mentioned above, there are no data on hydration of $\mathrm{SO}$ or dehydration of $\mathrm{S}(\mathrm{OH})_{2}$, so there is no interconversion between sulfur monoxide and sulfoxylic acid. Some researchers assume that the reduction of sulfite to sulfide is likely to proceed through a siroheme-bound sulfoxylate $\left(\mathrm{SO}_{2}{ }^{2-}\right)$ [92,97-99] (see Scheme 5). In this case the intermediate represents a complex of $\mathrm{Fe}^{3+}$ with a very strong reductant-sulfoxylate, and an inner electron transfer is very likely.

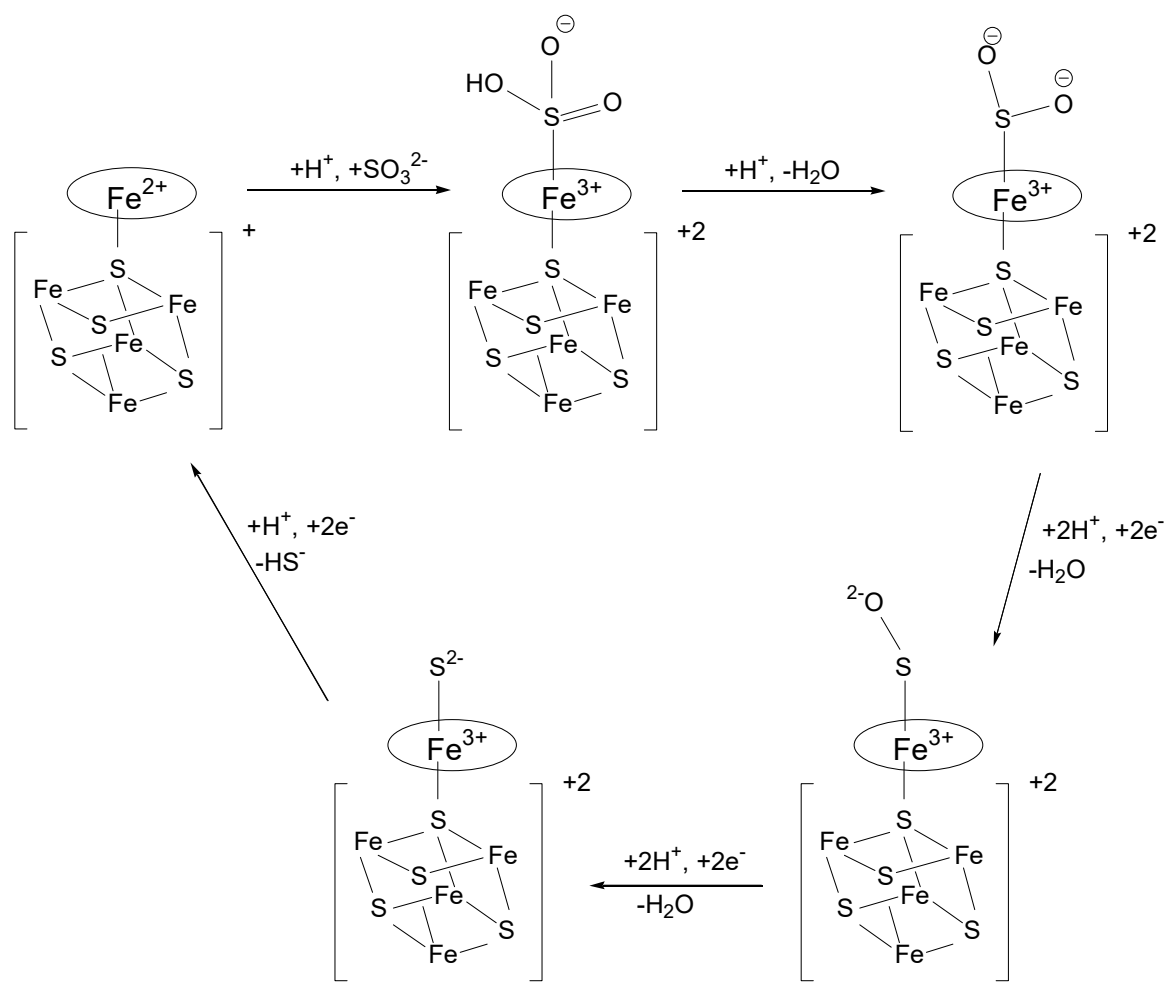

Scheme 5. Previously proposed catalytic cycle [100] for sulfite reductase based on results of Crane and coworkers [97-99]. Reproduced from permission from [100]. 
Finally, we have proposed a catalytic cycle for the enzyme. The last steps of the cycle include the formation of Fe-SO adducts, proposed to be a critical step in this cycle [101]. Linkage isomerism is possible in Fe-SO models and $\mathrm{Fe}^{2+}-\mathrm{SO}^{0}$ can shift to its $\mathrm{OS}$ form $[102,103]$. This FeOS intermediate would lead to a possible alternative route.

\section{Conclusions}

As can be seen from the discussion, oxidation of hydrogen sulfide may lead to formation of a very reactive reductant-sulfoxylic acid. This differs $\mathrm{H}_{2} \mathrm{~S}$ from the other very valuable biologically SH-compound - cysteine. Indeed, the analog of cysteine-cysteinesulfinic acid-practically has no reducing properties, for example, it cannot even reduce aquacobalamin [104]. These differences should be considered when comparing the biological roles of hydrogen sulfide and cysteine. The strong reducing properties of sulfoxylate may also be taken into consideration in the chemistry of sulfite reductases.

Author Contributions: S.V.M. and A.S.M. wrote the main article. A.K.H. revised the manuscript.

Acknowledgments: This work was supported by Russian Foundation for Basic Research, project 16-03-00162 (to S.V.M.) and by the GINOP-2.3.2-15-2016-00049 grant (to A.K.H.). The study was also financed by the Higher Education Institutional Excellence Programme of the Ministry for Innovation and Technology in Hungary within the framework of sustainable environment of the University of Pécs, as well as EFOP 3.6.1-16-2016-00004 entitled by Comprehensive Development for Implementing Smart Specialization Strategies at the University of Pécs. Financial support of the Hungarian Research Fund NKFIH-OTKA Grant. No. K116591 is also acknowledged.

Conflicts of Interest: The authors declare no conflict of interest.

\section{References}

1. Giles, G.I.; Tasker, K.M.; Jacob, C. Hypothesis: The role of reactive sulfur species in oxidative stress. Free Radic. Biol. Med. 2001, 31, 1279-1283. [CrossRef]

2. Giles, G.I.; Nasim, M.J.; Ali, W.; Jacob, C. The Reactive Sulfur Species Concept: 15 Years On. Antioxidants 2017, 6, 38. [CrossRef]

3. Gruhlke, M.C.H.; Slusarenko, A.J. The biology of reactive sulfur species. Plant Physiol. Biochem. 2012, 59, 98-107. [CrossRef]

4. Olson, K.R.; Gao, Y.; Arif, F.; Arora, K.; Patel, S.; DeLeon, E.R.; Sutton, T.R.; Feelisch, M.; Cortese-Krott, M.M.; Straut, K.D. Metabolism of hydrogen sulfide $\left(\mathrm{H}_{2} \mathrm{~S}\right)$ and Production of Reactive Sulfur Species (RSS) by superoxide dismutase. Redox Biol. 2018, 15, 74-85. [CrossRef]

5. DeLeon, E.R.; Gao, Y.; Huang, E.; Arif, M.; Arora, N.; Divietro, A.; Patel, S.; Olson, K.R. A case of mistaken identity: Are reactive oxygen species actually reactive sulfide species? Am. J. Physiol. Regul. Integr. Comp. Physiol. 2016, 310, R549-R560. [CrossRef]

6. Cortese-Krott, M.M.; Koning, A.; Kuhnle, G.G.C.; Nagy, P.; Bianco, C.L.; Pasch, A.; Wink, D.A.; Fukuto, J.M.; Jackson, A.A.; van Goor, H.; et al. The Reactive Species Interactome: Evolutionary Emergence, Biological Significance and Opportunities for Redox Metabolomics and Personalized Medicine. Antioxid. Redox Signal. 2017, 27, 684-712. [CrossRef]

7. Furdui, C.M.; Poole, L.B. Chemical approaches to detect and analyze protein sulfenic acids. Mass Spectrom. Rev. 2014, 33, 126-146. [CrossRef]

8. Poole, L.B. The Basics of Thiols and Cysteines in Redox Biology and Chemistry. Free Radic. Biol. Med. 2015, 0, 148-157. [CrossRef]

9. Ida, T.; Sawa, T.; Ihara, H.; Tsuchiya, Y.; Watanabe, Y.; Kumagai, Y.; Suematsu, M.; Motohashi, H.; Fujii, S.; Matsunaga, T.; et al. Reactive cysteine persulfides and S-polythiolation regulate oxidative stress and redox signaling. PNAS 2014, 111, 7606-7611. [CrossRef]

10. Kimura, H.; Shibuya, N.; Kimura, Y. Hydrogen Sulfide is a Signaling Molecule and a Cytoprotectant. Antioxid. Redox Signal. 2012, 17, 45-57. [CrossRef]

11. Betterton, E.A.; Hoffmann, M.R. Kinetics and Mechanism of the Oxidation of Aqueous Hydrogen Sulfide by Peroxymonosulfate. Environ. Sci. Technol. 1990, 24, 1819-1824. [CrossRef] 
12. Kumar, M.R.; Farmer, P.J. Chemical trapping and characterization of small oxoacids of sulfur (SOS) generated in aqueous oxidations of $\mathrm{H}_{2}$ S. Redox Biol. 2018, 14, 485-491. [CrossRef]

13. Makarov, S.V. Recent trends in the chemistry of sulfur-containing reducing agents. Russ. Chem. Rev. 2001, 70, 885-895. [CrossRef]

14. Frandsen, B.N.; Wennberg, P.O.; Kjaergaard, H.G. Identification of OSSO as a near-UV absorber in the Venusian atmosphere. Geophys. Res. Lett. 2016, 43, 11146-11155. [CrossRef]

15. Longobardi, L.E.; Wolter, V.; Stephan, D.W. Frustrated Lewis Pair Activation of an N-Sulfinylamine: A Source of Sulfur Monoxide. Angew. Chem. Int. Ed. 2015, 54, 809-812. [CrossRef]

16. Makarov, S.V.; Horváth, A.K.; Silaghi-Dumitrescu, R.; Gao, Q. Sodium Dithionite, Rongalite and Thiourea Oxides. Chemistry and Application; World Scientific: London, UK; Singapore, 2017; p. 219.

17. Makarov, S.V.; Makarova, A.S.; Silaghi-Dumitrescu, R. Sulfoxylic and thiosulfurous acids and their derivatives. In The Chemistry of Peroxides. PATAI's Chemistry of Functional Groups; Greer, A., Liebman, J.F., Eds.; Wiley: Chichester, UK, 2014; Volume 3, Part 1; pp. 265-305.

18. Makarov, S.V.; Horváth, A.K.; Silaghi-Dumitrescu, R.; Gao, Q. Recent Developments in the Chemistry of Thiourea Oxides. Chem. Eur. J. 2014, 20, 14164-14176. [CrossRef]

19. Makarov, S.V.; Silaghi-Dumitrescu, R. Sodium dithionite and its relatives: Past and present. J. Sulfur Chem. 2013, 34, 444-449. [CrossRef]

20. Frank, A.J.; Sadílek, M.; Ferrier, J.G.; Tureček, F. Hydroxysulfinyl Radical and Sulfinic Acid are Stable Species in the Gas Phase. J. Am. Chem. Soc. 1996, 118, 11321-11322. [CrossRef]

21. DellaGuardia, R.A.; Johnston, F.J. Radiation-Induced Reaction of Sulfur and Water. Radiat. Res. 1980, 84, 259-264. [CrossRef]

22. Carlson, R.W.; Anderson, M.S.; Johnson, R.E.; Schulman, M.B.; Yavrouian, A.H. Sulfuric Acid Production on Europa: The Radiolysis of Sulfur in Water Ice. Icarus 2002, 157, 456-463. [CrossRef]

23. Dereven'kov, I.A.; Salnikov, D.S.; Makarov, S.V.; Boss, G.R.; Koifman, O.I. Kinetics and mechanism of oxidation of super-reduced cobalamin and cobinamide species by thiosulfate, sulfite and dithionite. Dalton Trans. 2013, 42, 15307-15316. [CrossRef]

24. Čermák, V. Polarografickã studie dithioničitanu sodného. Chem. Zvesti 1954, 8, 713-720.

25. Čermák, V.; Smutek, M. Mechanism of decomposition of dithionite in aqueous solutions. Coll. Czech. Chem. Commun. 1975, 40, 3241-3264. [CrossRef]

26. Tyndall, G.S.; Ravishankara, A.R. Atmospheric oxidation of reduced sulfur species. Int. J. Chem. Kinet. 1991, 23, 483-527. [CrossRef]

27. Cazzoli, G.; Lattanzi, T.; Kirsch, T.; Gauss, J.; Tercero, B.; Cernicharo, J.; Puzzarini, C. Laboratory measurements and astronomical search for the HSO radical. Astron. Astrophys. 2016, 591, A126. [CrossRef]

28. Vairavamurthy, M.A.; Zhou, W. Characterization of a transient +2 sulfur oxidation state intermediate from oxidation of aqueous sulfite. In Geochemical Transformations of Sedimentary Sulfur; Vairavamurthy, M.A., Shoonen, M.A.A., Eds.; ACS: Washington DC, USA, 1995; pp. 280-292.

29. Tossell, J.A. Theoretical studies on possible sulfur oxides with +2 oxidation states in aqueous solution. Chem. Geol. 1997, 141, 93-103. [CrossRef]

30. Crabtree, K.N.; Martinez, O.; Barreau, L.; Thorwirth, S.; McCarthy, M.C. Microwave detection of sulfoxylic acid (HOSOH). J. Phys. Chem. A 2013, 117, 3608-3613. [CrossRef]

31. Napolion, B.; Huang, M.J.; Watts, J.D. Coupled-cluster study of isomers of $\mathrm{H}_{2} \mathrm{SO}_{2}$. J. Phys. Chem. A 2008, 112, 4158-4164. [CrossRef]

32. Eldridge, D.L.; Guo, W.; Farquhar, J. Theoretical estimates of equilibrium sulfur isotope effects in aqueous sulfur systems: Highlighting the role of isomers in the sulfite and sulfoxylate systems. Geochim. Cosmochim. Acta 2016, 195, 171-200. [CrossRef]

33. Smardzewski, R.R.; Lin, M.C. Matrix reactions of oxygen atoms with $\mathrm{H}_{2} \mathrm{~S}$ molecules. J. Chem. Phys. 1977, 66, 3197-3204. [CrossRef]

34. Iraqi, M.; Schwarz, H. Experimental evidence for the gas phase existence of $\mathrm{HSOH}$ (hydrogen thioperoxide) and $\mathrm{SOH}_{2}$ (thiooxonium ylide). Chem. Phys. Lett. 1994, 221, 359-362. [CrossRef]

35. Winnewisser, G.; Lewen, F.; Thorwirth, S.; Behnke, M.; Hahn, J.; Gauss, J.; Herbst, E. Gas-Phase Detection of HSOH: Synthesis by Flash Vacuum Pyrolysis of Di-tert-butyl Sulfoxide and Rotational-Torsional Spectrum. Chem. Eur. J. 2003, 9, 5501-5510. [CrossRef] 
36. Beckers, H.; Esser, S.; Metzroth, T.; Behnke, M.; Willner, H.; Gauss, J.; Hahn, J. Low-Pressure Pyrolysis of $t$-Bu ${ }_{2} \mathrm{SO}$ : Synthesis and IR Spectroscopic Detection of HSOH. Chem. Eur. J. 2006, 12, 832-844. [CrossRef]

37. Bogdándy, V.; Ida, T.; Sutton, T.R.; Bianco, C.; Ditrói, T.; Koster, G.; Henthorn, H.A.; Minnion, M.; Toscano, J.P.; van der Vliet, A.; et al. Speciation of reactive sulfur species and their reactions with alkylating agents: Do we have any clue about what is present inside the cell? Br. J. Pharmacol. 2019, 176, 646-670. [CrossRef]

38. Nagy, P.; Ashby, M.T. Reactive Sulfur Species: Kinetics and Mechanisms of the Oxidation of Cysteine by Hypohalous Acid to Give Cysteine Sulfenic Acid. J. Am. Chem. Soc. 2007, 129, 14082-14091. [CrossRef]

39. Kumar, M.; Francisco, J.S. Elemental sulfur aerosol-forming mechanism. Proc. Natl. Acad. Sci. USA 2017, 114, 864-869. [CrossRef]

40. Filipovic, M.R.; Zivanovic, J.; Alvarez, B.; Banerjee, R. Chemical Biology of $\mathrm{H}_{2} \mathrm{~S}$ Signaling through Persulfidation. Chem. Rev. 2018, 118, 1253-1337. [CrossRef]

41. Benchoam, D.; Cuevasanta, E.; Möller, M.N.; Alvarez, B. Hydrogen Sulfide and Persulfides Oxidation by Biologically Relevant Oxidizing Species. Antioxidants 2019, 8, 48. [CrossRef]

42. Rábai, G.; Orbán, M.; Epstein, I.R. A Model for the pH-Regulated Oscillatory Reaction between Hydrogen Peroxide and Sulfide Ion. J. Phys. Chem. 1992, 96, 5414-5419. [CrossRef]

43. Nagy, P.; Pálinkás, Z.; Nagy, A.; Budai, B.; Tóth, I.; Vasas, A. Chemical aspects of hydrogen sulfide measurements in physiological samples. Biochim. Biophys. Acta (BBA)-Gen. Subj. 2014, 1840, 876-891. [CrossRef]

44. Toohee, J.I. Hydrosulfide derivatives of cobalamins. J. Inorg. Biochem. 1993, 49, 189-199. [CrossRef]

45. Salnikov, D.S.; Kucherenko, P.N.; Dereven'kov, I.A.; Makarov, S.V.; van Eldik, R. Kinetics and mechanism of the reaction of hydrogen sulfide with cobalamin in aqueous solution. Eur. J. Inorg. Chem. 2014, 2014, 852-862. [CrossRef]

46. Zhu, J.; Petit, K.; Colson, A.O.; de Bolt, S.; Sevilla, M.D. Reactions of Sulfhydryl and Sulfide Radicals with Oxygen, Hydrogen Sulfide, Hydrosulfide, and Sulfide: Formation of $\mathrm{SO}_{2}{ }^{-}, \mathrm{HSSH}^{-}$, $\mathrm{HSS} \bullet^{2-}$ and HSS•. J. Phys. Chem. 1991, 95, 3676-3681. [CrossRef]

47. Toohee, J.I. Possible Involvement of Hydrosulfide in $\mathrm{B}_{12}$-Dependent Methyl Group Transfer. Molecules 2017, 22, 582. [CrossRef]

48. Salnikov, D.S.; Makarov, S.V.; van Eldik, R.; Kucherenko, P.N.; Boss, G.R. Kinetics and mechanism of the reaction of hydrogen sulfide with diaquacobinamide in aqueous solution. Eur. J. Inorg. Chem. 2014, 2014, 4123-4133. [CrossRef]

49. Carballal, S.; Trujillo, M.; Cuevasanta, E.; Bartesaghi, S.; Möller, M.N.; Folkes, L.K.; García-Bereguaiaín, M.A.; Gutiérrez-Merino, C.; Wardman, P.; Denicola, A.; et al. Reactivity of hydrogen sulfide with peroxynitrite and other oxidants of biological interest. Free Radic. Biol. Med. 2011, 50, 196-205. [CrossRef]

50. Ajibola, R.O.; Simoyi, R.H. S-Oxygenation of Thiocarbamides IV: Kinetics of Oxygenation of Tetramethylthiourea by Aqueous Bromine and Acidic Bromate. J. Phys. Chem. A 2011, 115, 2735-2744. [CrossRef]

51. Chigwada, T.; Mbiya, W.; Chipiso, K.; Simoyi, R.H. S-Oxygenation of Thiocarbamides V: Kinetics of Oxygenation of Tetramethylthiourea by Chlorite in Slightly Acidic Media. J. Phys. Chem. A 2014, 118, 5903-5914. [CrossRef]

52. Dereven'kov, I.A.; Ivlev, P.A.; Salnikov, D.S.; Bischin, C.; Attia, A.A.A.; Silaghi-Dumitrescu, R.; Makarov, S.V. Studies of reaction of tetramethylthiourea with hydrogen peroxide. Evidence of formation of tetramethylthiourea monoxide as a key intermediate of the reaction. J. Sulfur Chem. 2017, 38, 496-509. [CrossRef]

53. Walter, W.; Rohloff, C. On the oxidation products of carbothioamides, XXXI. Preparation and configuration of tetra- and trialkylthiourea S,S,S-trioxides. Justus Liebigs Ann. Chem. 1975, 295-304. [CrossRef]

54. Walter, W.; Rue $\beta$, K.-P. On the oxidation products of carbothioamides, XXX. Configuration and hindered internal rotation in aryl-trialkyl-substituted thioureas, thiourea S-trioxides, and formamidinium salts: Separation of geometric isomers of aryl-trialkyl-substituted thiourea S-trioxides. Justus Liebigs Ann. Chem. 1974, 253-273.

55. Csekö, G.; Pan, C.; Gao, Q.; Horváth, A.K. Kinetics of the Two-Stage Oxidation of Sulfide by Chlorine Dioxide. Inorg. Chem. 2018, 57, 10189-10198. [CrossRef]

56. Horváth, A.K.; Nagypál, I. Kinetics and Mechanism of the Reaction between Thiosulfate and Chlorine Dioxide. J. Phys. Chem. A 1998, 102, 7267-7272. [CrossRef] 
57. Horváth, A.K.; Nagypál, I. Kinetics and Mechanism of the Oxidation of Sulfite by Chlorine Dioxide in a Slightly Acidic Medium. J. Phys. Chem. A 2006, 110, 4753-4758. [CrossRef]

58. Svarovsky, S.A.; Simoyi, R.H.; Makarov, S.V. Reactive oxygen species in aerobic decomposition of thiourea dioxides. J. Chem. Soc. Dalton Trans. 2000, 511-514. [CrossRef]

59. Makarov, S.V.; Kudrik, E.V.; van Eldik, R.; Naidenko, E.V. Reactions of methyl viologen and nitrite with thiourea dioxide. New opportunities for an old reductant. J. Chem. Soc. Dalton Trans. 2002, 4074-4076. [CrossRef]

60. Makarov, S.V.; Sal'nikov, D.S.; Pogorelova, A.S. Acid-base properties of sulfoxylic acid in aqueous solutions. Russ. J. Inorg. Chem. 2010, 55, 301-304. [CrossRef]

61. Svarovsky, S.A.; Simoyi, R.H.; Makarov, S.V. A Possible Mechanism of Thiourea-Based Toxicities: Kinetics and Mechanism of Decomposition of Thiourea Dioxides in Alkaline Solutions. J. Phys. Chem. 2001, 105, 12634-12643. [CrossRef]

62. Hu, H.-Y.; Goto, N.; Fujie, K. Effect of $\mathrm{pH}$ on the reduction of nitrite in water by metallic iron. Water Res. 2001, 35, 2789-2793. [CrossRef]

63. Fanning, J.C.; Brooks, B.C.; Hoeglund, A.B.; Pelletier, D.A.; Wadford, J.A. The reduction of nitrate and nitrite ions in basic solution with sodium borohydride in the presence of copper(II) ions. Inorg. Chim. Acta 2000, 310, 115-119. [CrossRef]

64. Makarov, S.V.; Polenov, Y.V.; Budanov, V.V. Polarographic study on rongalite decompositions in aqueous solutions. Zhurn. Neorg. Khim. 1984, 29, 2456-2460.

65. Kudrik, E.V.; Makarov, S.V.; Zahl, A.; van Eldik, R. Kinetics and Mechanism of the Iron Phthalocyanine Catalyzed Reduction of Nitrite by Dithionite and Sulfoxylate in Aqueous Solution. Inorg. Chem. 2005, 44, 6470-6475. [CrossRef]

66. Mot, A.; Kis, Z.; Svistunenko, D.A.; Damian, G.; Silaghi-Dumitrescu, R.; Makarov, S.V. “Super-reduced” iron under physiologically-relevant conditions. Dalton Trans. 2010, 39, 1464-1466. [CrossRef]

67. Pogorelova, A.S.; Makarov, S.V.; Ageeva, E.S.; Silaghi-Dumitrescu, R. Cobalt phthalocyanine as a catalyst of the reduction of nitrite with thiourea dioxide. Russ. J. Phys. Chem. A 2009, 83, 2050-2053. [CrossRef]

68. Vlasova, E.A.; Makarov, S.V.; Malinkina, M.N. The kinetics of nitrite reduction by thiourea dioxide in the presence of cobalt octasulfophenyltetrapyrazinoporphyrazine. Russ. J. Phys. Chem. A 2010, 84, 655-660. [CrossRef]

69. Dereven'kov, I.A.; Ivanova, S.S.; Kudrik, E.V.; Makarov, S.V.; Makarova, A.S.; Stuzhin, P.A. Comparative study of reactions between $\mu$-nitrido or $\mu$-oxo-bridged iron tetrasulfophthalocyanines and sulfur-containing reductants. J. Serb. Chem. Soc. 2013, 78, 1513-1530. [CrossRef]

70. Salnikov, D.S.; Dereven'kov, I.A.; Makarov, S.V.; Ageeva, E.S.; Lupan, A.; Surducan, M.; Silaghi-Dumitrescu, R. Kinetics of reduction of cobalamin by sulfoxylate in aqueous solutions. Rev. Roum. Chim. 2012, 57, 353-359.

71. Song, J.S.; Kim, E.H.; Kang, S.K.; Yun, S.S.; Suh, I.-H.; Choi, S.-S.; Lee, S.; Jensen, W.P. The Structure and Ab Initio Studies of Thiourea Dioxide. Bull. Korean Chem. Soc. 1996, 17, 201-205.

72. Makarov, S.V.; Kuznetsova, A.A.; Salnikov, D.S.; Kiseleva, A.G. Effect of Glycine and Monoethanolamine on the Stability and Reductive Activity of Thiourea Dioxide in Aqueous Solutions. Russ. J. Gen. Chem. 2018, 88, 646-649. [CrossRef]

73. Zhou, L.; Shan, J.; Liu, X.; Shao, J. Study of the application of modified thiourea dioxide discharge agent in D5 non-aqueous medium. Color. Technol. 2015, 131, 149-156. [CrossRef]

74. Shao, J.; Liu, X.; Makarov, S.V.; Pei, K. TDO structure investigation in aqueous solution by TOF-MS, UV, Raman and quantum chemistry calculations. J. Sulfur Chem. 2019, 40, 426-434. [CrossRef]

75. Csekő, G.; Hu, Y.; Song, Y.; Kégl, T.R.; Gao, Q.; Makarov, S.V.; Horváth, A.K. Kinetic Evidence of Tautomerism of Thiourea Dioxide in Aqueous Acidic Solutions. Eur. J. Inorg. Chem. 2014, 2014, 1875-1879. [CrossRef]

76. Xu, L.; Valkai, L.; Kuznetsova, A.A.; Makarov, S.V.; Horváth, A.K. Kinetics and Mechanism of the Oxidation of Thiourea Dioxide by Iodine in a Slightly Acidic Medium. Inorg. Chem. 2017, 56, 4679-4687. [CrossRef]

77. Csekő, G.; Gao, Q.; Xu, L.; Horváth, A.K. Autocatalysis-Clock Reaction III: Clarifying the Kinetics and Mechanism of the Thiourea Dioxide-Iodate Reaction in an Acidic medium. J. Phys. Chem. A 2019, 123, 1740-1748.

78. Csekő, G.; Gao, Q.; Takács, A.; Horváth, A.K. Exact Concentration Dependence of the Landolt Time in the Thiourea Dioxide-Bromate Substrate-Depletive Clock Reaction. J. Phys. Chem. A 2019, 123, 3959-3968. [CrossRef] 
79. Lyons, D.; Nickless, G. The lower oxy-acids of sulphur. In Inorganic Sulphur Chemistry; Nickless, G., Ed.; Elsevier: New York, NY, USA, 1968; pp. 509-534.

80. Bestgen, S.; Roesky, P.W. SO ${ }^{2+}$ : Closing a Gap in Sulfur Oxide Chemistry. Angew. Chem. Int. Ed. 2018, 57, 1148-1150. [CrossRef]

81. Wu, Z.; Lu, B.; Feng, R.; Xu, J.; Li, Y.; Wan, H.; Eckhardt, A.K.; Schreiner, P.R.; Xie, C.; Guo, H.; et al. Capture of $\mathrm{SO}_{3}$ isomers in the oxidation of sulfur monoxide with molecular oxygen. Chem. Commun. 2018, 54, 1690-1693. [CrossRef]

82. Chao, P.; Lemal, D.M. Sulfur Monoxide Chemistry. Stereochemistry of the Thiirane Oxide-Diene Reaction. J. Am. Chem. Soc. 1973, 95, 920-922. [CrossRef]

83. Grainger, R.S.; Procopio, A.; Steed, J.W. A Novel Recyclable Sulfur Monoxide Transfer Reagent. Org. Lett. 2001, 3, 3565-3568. [CrossRef]

84. Abu-Yosef, I.A.; Harpp, D.N. Effective Precursors for Sulfur Monoxide Formation. J. Org. Chem. 1997, 62, 8366-8371. [CrossRef]

85. Schenk, W.A.; Leißner, J.; Burschka, C. Stabilisierung von Schwefelmonoxid durch Koordination an Übergangsmetalle. Angew. Chem. 1984, 96, 787-788. [CrossRef]

86. Pandey, K.K.; Patidar, S.K.; Vishwakarma, R. Theoretical insights into M-SO bonds in transition metal-sulfur monoxide complexes [ $\left.\left[\mathrm{N}\left(\mathrm{SPMe}_{2}\right)_{2} \mathrm{MSO}\right)\right]$ : Assessment of density functional and dispersion interactions. Polyhedron 2015, 101, 230-238. [CrossRef]

87. Wei, R.; Chen, X.; Gong, Y. Side-On Sulfur Monoxide Complexes of Tantalum, Niobium, and Vanadium Oxyfluorides. Inorg. Chem. 2019, 58, 3807-3814. [CrossRef]

88. Lemal, D.M.; Chao, P. Sulfur Monoxide Chemistry. The Nature of SO from Thiirane Oxide and the Mechanism of its Reaction with Dienes. J. Am. Chem. Soc. 1973, 95, 922-924. [CrossRef]

89. Joost, M.; Nava, M.; Transue, W.J.; Martin-Drumel, M.-A.; McCarthy, M.C.; Patterson, D.; Cummins, C.C. Sulfur monoxide thermal release from an anthracene-based precursor, spectroscopic identification, and transfer reactivity. PNAS 2018, 115, 5866-5871. [CrossRef]

90. Salama, F.; Frei, H. Near-Infrared-Light-Induced Reaction of Singlet SO with Allene and Dimethylacetylene in a Rare Gas Matrix. Infrared Spectra of Two Novel Episulfoxides. J. Phys. Chem. 1989, 93, 1285-1292. [CrossRef]

91. Mirts, E.N.; Petrik, I.D.; Hosseinzadeh, P.; Nilges, M.J.; Lu, Y. A designed heme-[4Fe-4S] metalloenzyme catalyzes sulfite reduction like native enzyme. Science 2018, 361, 1098-1101. [CrossRef]

92. Parey, K.; Warkentin, E.; Kroneck, P.M.H.; Ermler, U. Reaction Cycle of the Dissimilatory Sulfite Reductase from Archaeoglobus fulgidus. Biochemistry 2010, 49, 8912-8921. [CrossRef]

93. Oliveira, T.F.; Vonhrein, C.; Matias, P.M.; Venceslau, S.S.; Pereira, I.A.C.; Archer, M. The Crystal Structure of Desulfovibrio vulgaris Dissimilatory Sulfite Reductase Bound to DsrC Provides Novel Insights into the Mechanism of Sulfate Respiration. J. Biol. Chem. 2008, 283, 34141-34149. [CrossRef]

94. Santos, A.A.; Venceslau, S.S.; Grein, F.; Leavitt, W.D.; Dahl, C.; Johnston, D.T.; Pereira, I.A.C. A protein trisulfide couples dissimilatory sulfite reduction to energy conservation. Science 2015, 350, 1514-1545. [CrossRef]

95. Bradley, A.S.; Leavitt, W.D.; Johnston, D.T. Revisiting the dissimilatory sulfate reduction pathway. Geobiology 2011, 9, 446-457. [CrossRef]

96. Wing, B.A.; Halevy, I. Intracellular metabolite levels shape sulfur isotope fractionation during microbial sulfate respiration. Proc. Natl. Acad. Sci. USA 2014, 111, 18116-18125. [CrossRef]

97. Crane, B.R.; Siegel, L.M.; Getzoff, E.D. Sulfite Reductase Structure at 1.6 Å: Evolution and Catalysis for Reduction of Inorganic Anions. Science 1995, 270, 59-67. [CrossRef]

98. Crane, B.R.; Siegel, L.M.; Getzoff, E.D. Structures of the Siroheme- and $\mathrm{Fe}_{4} \mathrm{~S}_{4}$-Containing Active Center of Sulfite Reductase in Different States of Oxidation: Heme via Reduction-Gated Exogenous Ligand Exchange. Biochemistry 1997, 36, 12101-12119. [CrossRef]

99. Crane, B.R.; Siegel, L.M.; Getzoff, E.D. Probing the Catalytic Mechanism of Sulfite Reductase by X-ray Crystallography: Structures of the Escherichia coli Hemoprotein in Complex with Substrates, Inhibitors, Intermediates and Products. Biochemistry 1997, 36, 12120-12137. [CrossRef]

100. Silaghi-Dumitrescu, R.; Makarov, S.V. Siroheme-Containing Sulfite Reductase: A Density Functional Investigation of the Mechanism. Int. J. Quant. Chem. 2012, 112, 900-908. [CrossRef] 
101. Surducan, M.; Makarov, S.V.; Silaghi-Dumitrescu, R. O-S Bond Activation in Structures Isoelectronic with Ferric Peroxide Species Known in O-O-Activating Enzymes: Relevance for Sulfide Activation and Sulfite Reductases. Eur. J. Inorg. Chem. 2014, 2014, 5827-5837. [CrossRef]

102. Surducan, M.; Lup, D.; Lupan, A.; Makarov, S.V.; Silaghi-Dumitrescu, R. Electromerism and linkage isomerism in biologically-relevant Fe-SO complexes. J. Inorg. Biochem. 2013, 118, 13-20. [CrossRef]

103. Surducan, M.; Brânzanic, A.M.V.; Silaghi-Dumitrescu, R. Heme Fe-SO ${ }^{2-}$ intermediates in sulfite reduction: Contrasts with $\mathrm{Fe}_{-} \mathrm{OO}^{2-}$ species from oxygen-oxygen bond activating systems. Int. J. Quant. Chem. 2018, e25697. [CrossRef]

104. Dereven'kov, I.A.; Tsaba, L.V.; Pokrovskaya, E.A.; Makarov, S.V. Studies on the interaction of aquacobalamin with cysteinesulfinic and cysteic acids, hypotaurine and taurine. J. Coord. Chem. 2018, 71, 3194-3206. [CrossRef]

(C) 2019 by the authors. Licensee MDPI, Basel, Switzerland. This article is an open access article distributed under the terms and conditions of the Creative Commons Attribution (CC BY) license (http://creativecommons.org/licenses/by/4.0/). 